\title{
Surviving in the Particular? Uni(versali)ty and Multiplicity in the Novels of Richard Powers
}

Heinz Ickstadt

\section{(2) OpenEdition \\ Journals}

Electronic version

URL: https://journals.openedition.org/ejas/1119

DOI: 10.4000/ejas.1119

ISSN: 1991-9336

Publisher

European Association for American Studies

\section{Electronic reference}

Heinz Ickstadt, "Surviving in the Particular? Uni(versali)ty and Multiplicity in the Novels of Richard Powers", European journal of American studies [Online], 2-1 | 2007, document 1, Online since 22 May 2007, connection on 08 July 2021. URL: http://journals.openedition.org/ejas/1119 ; DOI: https:// doi.org/10.4000/ejas. 1119

This text was automatically generated on 8 July 2021.

Creative Commons License 


\title{
Surviving in the Particular? Uni(versali)ty and Multiplicity in the Novels of Richard Powers
}

\author{
Heinz Ickstadt
}

1 Although some of the 'masters' of postmodernism are still producing 'postmodern' narratives (e.g. Robert Coover with his recent Lucky Pierre), contemporary American fiction has largely moved 'back' into realism's territory of the everyday that the postmodernists had been so determined to abandon. It is true that, as in the case of Don DeLillo, this new realism is not grounded in any ontological notion of the 'real' but in an experienced 'hyper-reality' of surface and of image. Yet it makes nevertheless use of familiar conventions of realism: its emphasis on everyday experience, the importance of family, and the question (explored in conversation and communicative interaction) of shared values. White Noise would be an early case in point; yet more recently, Jonathan Franzen and Jeffrey Eugenides have pushed this tendency even farther away from postmodernist narrative deconstructions into the direction of the (ethnic) family (if not the 'national') epic - resuming the almost forgotten search for the great American novel.

2 It would seem plausible, therefore, to discuss Richard Powers's novels - especially his last three: Gain (1998), Plowing the Dark (2000) and The Time of Our Singing (2003) - in this particular context since they are not only 'epic' but also quite accessible. They thus seem to indicate his moving away from an earlier work that had shown affinity to novels like Joseph McElroy's Lookout Cartridge (1974) and Plus (1976), or DeLillo's Ratner's Star (1976), or, possibly, to Gaddis's JR (1975), i.e. to texts exploring the specialized languages of mathematics, the stock exchange, computer technology or the electronic media.

3 And yet, Powers's fictions have been consistently grounded in experience and history while exploring the various discourses of contemporary science and technology that have drastically widened our concept of the real during the last century. His work, from early on, has been ambitious in scope and encyclopaedic in the discursive ground 
it covered. Powers is a man of many different interests and abilities who, although an expert in classical music (and able to play several instruments), set out on a career in the natural sciences, but then acquired a Masters degree in English, became a computer programmer and freelance data processor. Until he saw, in a photo exhibition of the Boston Fine Arts Museum, August Sander's photograph of 1914, "Young Westerwald Farmers on Their Way to a Dance" which made him give up his job and write his first novel Three Farmers on Their Way to a Dance (1985). The young men's direct look at the spectator becomes an invitation to interpret history - a history that is still unknown to them but apparent to those who, positioned in the contemporary present, know the nature of the "dance" the future has in store for them. The novel is itself a narrative 'dance' between stories situated on different time levels and told in different voices and from different perspectives - "the past looking full-faced into the present and recognizing it," and the present creating itself in the recognition of the past. "Remembering forward," Powers called this in an interview; and the attempt at "trying to open a conversation" between different time periods, discourses, or areas of experience normally sealed off from each other remains a characteristic of his subsequent work. ${ }^{1}$

4 In his second novel, Prisoner's Dilemma (1988), the children of the Hobson family gradually discover the mystery of their father's fatal sickness and its hidden history: his escape from the traumatic experience of the first atomic explosion at Alamogordo (and the radiation he could not escape from) into the private utopia of a Disney-film fantasy world ("Hobstown"). Powers' third and, until then, most ambitious novel, The Gold Bug Variations (which became a cult book soon after its publication in 1991), links the discourse of genetics to that of musicology, and the structure of DNA to that of Bach's "Goldberg Variations," the "best metaphor for the living gene" (GV 579). He connects the structures of life with the structure of the mind, both present in the structure of the cell and of Bach's music:

that tightly bound, symmetry-laced catalog of unity" revealing "how nothing was the same as anything else. [...] It needs the conviction [...] that all things must be possible, sayable, particular, real (GV 586).

5 That "everything possible is real" was indeed one of Bach's favorite sayings. It echoes throughout Powers's fiction, but is of special relevance in a novel exploring the implications of the genetic code and that, roughly, follows the structure of the "Goldberg Variations" (Aria/Prologue - 30 Variations/Chapters - Aria/Epilogue).

6 Again, different time levels intersect and interweave in the temporal spiralling of the plot: 1957, when Dr. Ressler, an expert in genetics and engaged in deciphering the genetic code, is 25; and 1982/3, when Frank Todd, a would-be art historian and computer freak, then also 25, rediscovers the dropped-out and forgotten Ressler; and 1986 (the actual narrative present), when Jan O'Deigh, a reference librarian and Todd's former and future lover, tells the story of a past that is shaping the present in the very act of its telling. In the process, Jan, "the humanist becomes an autodidact scientist, replaying and reinterpreting the Neo-Darwinian synthesis, which the reader must also do, in following the course of her learning." While, inversely, Ressler, "the scientist finally becomes an autodidact humanist, spending the rest of his life composing music, the mathematics of the central nervous system" (Powers in Morrow). The symmetric set of characters and the choreography of their changing interrelation merge the love 
for life (and lover) with the desire for cognition: "all pieces amounted to love songs." For, if knowing is fundamentally related to loving and living,

the purpose of all science [...] was not the accumulation of Gnostic power, fixing of formulas for the names of God, stockpiling brutal efficiency, accomplishing the sadistic myth of progress. The purpose of science was to revive and cultivate a perpetual state of wonder (GV 611).

7 It was precisely this love for science as a love for life's (and the mind's) wonders that made Ressler resign from the reductionist restrictions of the field and from the frantic "gold rush" for the technological implementation of the scientifically wonderful. ${ }^{2}$

Powers's fourth and perhaps darkest novel, Operation Wandering Soul (1993), is focused on Richard Kraft, surgeon in a poor children's hospital in Los Angeles, and his progressive disintegration under the strain of a hopeless task: his having to operate on the daily influx of doomed, misshapen, mutilated and abandoned children. Powers connects his unveiling of the terrifying underside of contemporary social life (of war zones in American cities as much as in East Asian jungles) to a long history of children sacrificed to adult pipe dreams and utopias (the yearning for the heavenly city on earth), epitomized in the millennial children's crusades and the legend of the Piper of Hamlin which forms the subtext of the book. Looking back upon his early work, Powers speaks of his next book, Galatea 2.2 (1995) as a "compensatory movement" since his creative output seems, as he says, to oscillate between visions of darkness and creative possibility. Not only is the book stylistically simpler and more transparent than the one preceding it; it also works itself through despair and crisis back to a reaffirmation of the value of fiction. Galatea 2.2 is openly autobiographical. The protagonist, Richard Powers, artist-in-residence at a Midwest university and author of four novels, becomes involved in an Artificial Intelligence project. He teaches a computer how to read and write so that it may eventually participate in an intelligence contest. It grows from one level of intelligence to another according to the mind's method of self-creation through feed-back, memory and repetition. The artificial brain gradually grows to be the almost-person 'Helen' to whom Richard teaches the classics and the canon, i.e. the humanist education that he himself had received by his old teacher. This continues until he meets the lovely A. who confronts him with poststructuralist rejections of essentialism and the humanist ideal. Powers then 'feeds' Helen everything from theory to the horrors of daily news ${ }^{3}$ - until she falls into depressed and passive silence. Yet having been an object of human care, she can herself work as a catalyst of love and a new faith in fiction: she has, metaphorically, become Powers's 'child,' another of his artificial creations.

Galatea 2.2 is a reflection on how the mind works (Powers once called it an extended comment on Emily Dickinson's "The brain is wider than the sky...") as well as a selfreflexive fiction. It is also a reflection on past life as much as on past work: from a narrative present (situated in the personal crisis of a 'lost' year, the protagonist's $35^{\text {th }}$ ), the narrator/protagonist/author reinvents the situation of production for each of his earlier books, weaving a temporal and textual quilt (there are no chapter breaks) from a remembered past and an experienced present into a pattern that includes the future.

11 Galatea 2.2 also marks a (moderate) break between Powers's earlier and his subsequent work. It opens a window onto the autobiographical contexts of his previous fiction, only to close it once and for all. ${ }^{4}$ From now on, the dialogic opposition between the public and the private is defined in more objective, more historical and political terms. 
Although Powers conceives of the writer as re-inventing himself with each work, there is an unmistakable Powers signature throughout: the blending of different time levels ("a-synchronic messaging"); the contrapuntal or dialogic braiding of oppositional yet complementary plots; the exuberant play with puns and intertextual allusions (beyond literature to a wide range of texts); and, perhaps, more than anything else, his inclusion (if not preference) of "discursive narrative" next to (if not over) what he calls "dramatic revelation." His various narrative voices are, like those of Pynchon, impressively learned in highly complex and specialized discourses. They suggest an underlying inter-connectedness that remains, in the last instance, for the reader to establish. Although there is no postmodern deconstruction of the mimetic mode, nor a poststructuralist sense of confinement in the "prisonhouse of language," the basis of mimetic representation is nevertheless eroded since, in Powers's fiction, the mind is conceived of as being part of the reality it experiences - shaped by it and shaping it in the process of its own unfolding. Even if language cannot grasp the things it names, it can provide the codes and metaphors, the structures of cognition. If Ressler recognizes in Bach's music the structure of DNA and of life's processes, then Powers may well have found in Bach's "Goldberg Variations" the structure underlying his own work (constituting an interrelational or structural or functional mimesis of a special kind). ${ }^{5}$

His post-Galatea 2.2 novels - Gain (1998), Plowing the Dark (2000) and The Time of Our Singing (2003) - stay within the radius of this signature. They continue his interest in the reality of contemporary life as much as in the reality-creating power of specialized discourse, yet they enact it in the larger field of the collectively experienced. ${ }^{6}$ In his interview with Powers, Bradford Morrow speaks of an "impulse to weave individual narrative threads through the tapestry of some large historical moment or movement." In Gain, the public history of American capitalist ingenuity is told as a history of soap manufacturing. It is focused on the gradual expansion of the fictive company of Clare Soap - from its beginnings in the seventeenth century as a family business to the America-based global giant corporation it developed into during the course of the twentieth. ${ }^{7}$ A second strand of narrative tells a contemporary history of private life whose protagonist, Laura Bodey, the separated mother of two children, is slowly dying of cancer (which may or may not have been environmentally caused by the ubiquitous products of Clare Soap). ${ }^{8}$

Both these highly different 'family' narratives are braided contrapuntally together in a sequence of alternating chapters, the collective past increasingly catching up with and becoming part of the private present. Both narrative strands are interlaced with textual material that tie the public product to its private use (and users): from soap recipes and early advertisements to fact sheets and advertising slogans that change with the changes in Clare's long history, from the enterprise of the Clare brothers to the anonymous global corporation. Together, they unfold the story of the quasicancerous growth of a corporate system in which material and creative gain (and Powers insists on the creative aspects of capitalism) as much as environmental and personal loss are linked in a dense network of all-pervasive and inescapable complicity. They reveal how individual lives (and deaths) are inextricably enmeshed in a collective life whose conditions have become part of a given and accepted 'natural' environment. Although the novel rejects an all-too-easy causal link, it nevertheless suggests a deep and multiple interconnectedness since, as Powers argued in a comment on his book, "even the terms of individualism - even the invention of the individual itself - is a 
function of these larger institutional forces and historical processes" (Powers in Williams, "The Last Generalist" 8). ${ }^{9}$

In a similar and yet quite different way, Powers juxtaposes and interlinks two totally disconnected and secluded realms of experience in his next novel, Plowing the Dark. On the one hand, there is the self-enclosed world of a technological avant-garde working to create a substitute reality of complete simulation, and on the other the closed-off room where the kidnapped victim of an Arab terrorist group tries to keep mentally alive by reconstructing, word for word, the books he has read and by visualizing, minutely and painstakingly, the world he can no longer see. The book opens with a section evoking an island space of confinement (out of time and out of world) that may refer to either of the two realms. In the subsequent narrative, these are diametrically set against each other until, in the last chapters, they converge - by a miraculous leap of the imagination - to form one visionary space. Taimur Martin, an Iranian-American language teacher in Beirut and the protagonist of the terrorist plot-line, uses memory and the mind's image-making faculty as a means of survival in a situation of prolonged solitude and deprivation, while Adie Klarpot, once an artist of promise, is lured into joining a virtual reality project in Seattle (the "Cave Project" according to its grounding in a Platonic concept of the world). It is run by a team of artists and scientist dedicated to realize the ultimate dream of representation: a "self-contained virtual environment," the complete imitation of life by its most perfect substitution. Yeats's aesthetic utopia in "Sailing to Byzantium" is the subtext of this dream, whose realization in the digital age is the immortal immanence of a virtual existence beyond time and body, "humanity's final victory over the tyranny of matter"10 (PD 267).

The complicity between fantasies of an aesthetic counterworld and the lure of the visual/virtual becomes apparent when Adie, inspired by Yeats's poem, constructs a lifesize virtual model of the Hagia Sophia, "the Byzantine temple in Istanbul she associates with Yeats's 'artifice of eternity"' (Harris 256). When she comes to realize that "the Air Force had taken all her pretty pictures and put them to use" in the precision bombings of the first Gulf War (PD 397) and that "[h]er work here was just a rough draft for technology's wider plan" (398), she enters virtually the temple of her art as a soaring angel of destruction, "in the simulation but not of it." Falling "like a startled fledgling, back into the world's snare," she sees a man "staring up at her fall, his face an awed bitmap no artist could have animated" (399) Although nameless, it is - so we may assume - Taimur, freed from his blindfold, tumbling back into a world that has become for him a sacred temple and a visionary space: he sees an angel falling, "its bewilderment outstripping your own" (414).Is she the "truth that only solitude reveals" (414)? Or is it the need for such truth that provokes her falling?

16 Since the novel projects a world in which the imagination is put to such radically opposed uses, the question arises "whether the imagination is powerful enough to save ourselves from its power" (Powers in Williams, "The Last Generalist" 15) The novel cannot, of course, answer that question but it clearly opts for the saving power of memory and reading, where the world is creatively imagined, reflected and reconstructed at a remove from it. Like Galatea 2.2, Plowing the Dark is a passionate plea for the novel as a (counter)virtual space in which reality is not replaced but "reconstituted into something more survivable." ${ }^{11}$

17 The Time of Our Singing tries, in an even more complex fashion, to intertwine the public and the private, the discourses of music (its history, its harmonious and/or polyphonic 
structures, its temporal measure) and science (the Einsteinian concept of Time), on the one hand, with the cultural discourse and the social experience of race, on the other. As he did in Gain, Powers uses the genre of the family novel to tell a history of 'national' scope. ${ }^{12}$ Which is why some critics, although acknowledging their formal complexities, have linked his recent novels to a tradition of nineteenth-century fiction writing: "However idiosyncratic his technique," writes Daniel Mendelsohn in a review of The Time of Our Singing he titled "Hidden Harmonies," "the novelists whom Powers really resembles are the nineteenth-century behemoths, like Balzac or Zola or Tolstoy... He wants to make you hear [...] the concord that both underlies and explains the confusing jangle of modern life" (Mendelsohn 12). It is words like "concord" and "harmonies" that signal Mendelsohn's discomfort, since they associate Powers's book with outmoded concepts of coherence and organic wholeness that run counter to the contemporary emphasis on fragmentation and disruption. This, however, misses the brilliance as well as the courage of the book. It is brilliant because, rather than being about the discourse of music, it places itself within that discourse (thus making us participate in, 'live in,' the music that is sung). And it is courageous, because it works its way through a national history of racism and crosses racial, cultural, and linguistic borderlines. With the means of fiction, it explores the theoretically loaded question of whether the concept of an abstract universal can be reconciled with the lived reality of the particular.

Therefore, it is worthwhile to look at Powers's most recent novel (and his aesthetics in general) via the re-constructive perception of pragmatist thought, specifically the aesthetic theory of John Dewey, and not through the deconstructive eyes of contemporary theory. At first, this may seem like an arbitrary connection. Yet Powers's desire to cross boundaries of discourse, his "interdisciplinary vision," his self-definition as one of the last "generalists," his analogy between the complex interconnectedness of the literary text and "how the human organism works," his concept of the novel "as a supreme connecting machine - the most complex artifact of networking that we've ever developed," his characterization of the project of his writing as counteracting "the massive disconnection" that has come to separate life from art, his intention to make books "that link up pure aesthetic wonder and astonishment with a more mature accountability to intractable social questions" (Powers in Williams, "The Last Generalist") - all this resonates with Dewey's pragmatist aesthetics.

Pragmatism saw the aesthetic as a realm of creative self-assertion but also as a laboratory of thought and action, refusing the pressures of reductionism, of disconnecting "art from the objects and scenes of ordinary experience," as John Dewey argues in Art as Experience (Dewey 6). Dewey's vehement anti-essentialism is directed against the institutionalization of art as a quasi-transcendent realm removed from, and above, everyday experience. Since aesthetic experience was the epitome of all experience, art had to be continuous with life in order to be vital and creative.

Beginning with Experience and Nature (1925) and culminating in Art as Experience (1934), the late period of Dewey's thought coincides with a highly conflicted phase of transition in American intellectual history - not only because the First World War and the Depression had a profound impact on the American imagination, but also because the early thirties revealed deep ideological divisions and an increasing differentiation and specialization in American intellectual life. And yet, Dewey seems more concerned with continuities than with contemporary breaks and disruptions. Connecting, in his 
way of thinking, pre-modern progressivism with post-progressive modernism and the extreme modernism of the twenties with the 'anti-modernism' of the thirties, he built bridges, suggested organic unfoldings where others only saw collapse of social order and cultural coherence. Reaching backward and forward in time, he appeared bent on defining structural and anthropological constants in a continuous process of change and exchange - not by setting off one against the other but by thinking them together; as forming part of an ever expanding network of communicative interaction: 'bridging the gap between poetry and science,' between culture and the natural environment, between individual and collective life, between social practice and creative expression, between living art and the concrete experience of living.

21 Although Dewey considered tensions and conflicts (the breaking with conventions and taboos) as part of the liberating potential of art and its experience, and although he rejected the professional pressure toward building abstract or universalising systems, it seems nevertheless clear that his concept of art implied a unifying faith as much as a unifying project. It rested on the belief that art, although an individual object of expression, was yet grounded in communication and participation, and that its "office" was to remake "the experience of the community in the direction of greater order and unity" (Dewey 81).

This sounds, indeed, old-fashioned to ears used to the persuasive voice of postmodern/ poststructuralist scepticism. But we should remember that, for Dewey, words like “'unity, organic wholeness, order, fusion' are not metaphysical but dynamic and pragmatic terms; just as Dewey's concept of the 'universal' should not be understood as a metaphysical but as a hypothetical category, liable to change in the continuous process of creating, individually and collectively, meaning out of the process of experience. In other words, universality and diversity "are defined functionally." They are "both effects of social practice" (Menand 398). And yet, although not metaphysical, the universal has nevertheless something like a foundational resonance: "[T]hrough the phases of perturbation and conflict," Dewey writes, "there abides the deep-seated memory of an underlying harmony, the sense of which haunts life like the sense of being founded on a rock" (Dewey 17).

How universality and diversity can be brought into meaningful form by the symbolic and social practice of art is of course the question and the burning issue here. Although Dewey's "community" appears to imply the "great community" of a culturally homogeneous society, it is nevertheless conceived pluralistically, containing a plurality of cultures and communal groups. And although Dewey could never quite alleviate the tension between universalist and particularist interpretations of the communal, it is remarkable how easily the universalist claim can also be applied to the level of the local or to particular groups (as long as they are not re-essentialized in the process). Just as, inversely, by "remaking the experience" of a particular community, art may also open the particular toward something shared beyond the consciousness of difference. "In the end" - and I quote Dewey for the last time - "works of art are the only media of complete and unhindered communication between man and man that can occur in a world full of gulfs and walls that limit community of experience" (Dewey 105). In other words, although art accepts difference and is rich with particulars, it does not (and should not) dispense with the notion of a universal - however tentative and hypothetical, however 'questionable' (in a very fundamental sense) that notion may have become. 

together especially in Richard Powers's latest novel. With some exaggeration, one could even understand it as a fictional enactment of some of Dewey's reflections on art and aesthetic expression in a radically changed historical context. The Time of Our Singing traces the emptying out of a Western idea of universal culture during a century of racial hatred and mass murder on two continents ("to prove how a dream of music was never more than that" (611)). The racially mixed family of David and Delia Strom (she, an African American singer - he, a German Jewish mathematician) and their three mulatto children is based on their love for each other as well as on their love for (classical) music - a music they "own" because they love and skillfully practice it, live in it and by it. Their family-utopia falls apart, however, when the mother, whose caring and singing presence had held it together, dies (by either accident or racist crime). After her death, the dream of a transcendent and redemptive culture beyond race can no longer be sustained. Its naiveté (the "discredited dream," the declamatory emptiness of Beethoven's evocation of universal brotherhood) becomes glaringly apparent in face of the violent reality of racism, on the one hand, and of racial claims to cultural ownership, on the other. Can black people feel at home in a music that is not part of their own cultural heritage? Do they betray their culture if they do? Can a "white" novel like this one enter into the experience of another race? And if it does, is it an attempt at understanding or an act of appropriating the Other? ${ }^{13}$

On one hand, The Time of Our Singing is marked by the nostalgic glow of a lost (if culturally limited) universalist utopia whose ideal of inclusiveness has been tainted by a social practice of exclusion and repression. On the other, the story it tells follows the seemingly inevitable pull towards ethnic (or racial) particularity. For it is only here that culture may regain meaning through a reassertion of its social function, by giving shape and expression to the experience of a particular social (racial/ethnic) group.

"Home" and the quest for "belonging" are central themes which Powers weaves into the fabric of his novel as a motif with many variations. Take, for instance, that piece of folk wisdom which, as David discovers, is part of the black but also of the Jewish tradition: "The bird and the fish can fall in love. But where will they build their nest?" $(13,630)$. It expresses each ethnic groups' fear of assimilation ("We fear most being lost in likeness"), but also the dominant culture's fear of losing distinctness through mixing. The "nest" Delia and David build on the strength of their love and the promise of the humanist culture they embrace is an illusion in terms of past and present, and yet, possibly, also a promise in terms of future. For a brief period, it provides a precarious home not only for their mixed (and soon to be mixed-up children) but also for a classical musical tradition that, for centuries, had been anchored in the Family, in the communal practice of all of its members - sustained by them as well as, in turn, sustaining them through a daily intellectual diet of musical games and rituals (most famously, perhaps, in the case of the Bach family). In mid-twentieth century racist and commercialized America, this "home" has become an artificial environment, however, cut off from the hostile collective life surrounding it as much as from a dominant culture that has elevated the classical tradition into a white cultural institution.

When the Strom-family breaks apart, David withdraws into his esoteric reflections on the nature of Time, since he is incapable of protecting his children from the times they live in: a social context of increasing racial conflict. For it is the sixties and the Civil Rights movement that give the question of "belonging" a new and paradoxical 
dimension: "At the flick of that invented calendar switch, the world went from black and white to colored. And by some law of conserving physics, Jonah, Ruth, and I went from colored to black and white" (TS 197). The light-skinned Jonah tries to find place and success in the competitive business of musical performance, while he attempts, at the same time, to prove his loyalty to blackness by singing "his way back [...] into that moment before conquest, before the slave trade, before genocide" (TS 530) and by allowing himself to be fatally drawn to scenes of racial violence. His inability to choose or to keep the two parts of his heritage together quite literally chokes him. Joey, narrator of the family history and selfless accompanist of his brilliant brother, is unable to develop either with Jonah or apart from him. He eventually finds a place in the community created by the blackest of the three children, Ruth, who is 'rooted' in her rediscovered blackness. It is here, in Ruth's community school, where culture/ music is communally reinvented, where it becomes once more alive by being reconnected with its social function, where the family game of "crazed quotations" can be practiced again, that Joey comes into his own at last by composing and teaching music to black children.

In this book, there is no easy reconciliation - perhaps there is no reconciliation at all. The scars of private hurts and public mutilations (as in the horrible story of Emmett Till) that the experience of race hatred has left even on Jonah's consciousness run deep. But there is also a sense of historical change. Although racial violence continues and indirectly causes Jonah's death, the physical and mental terrors of Southern lynching in the thirties and fifties have given way to a new awareness of choice felt by a younger generation. This is evident in cousin Delia's relaxed, almost Zora Neale Hurston-like ${ }^{14}$ concept of cultural exchange: "We're making a little country here, out of mutual theft. They come over into our neck of the woods, take all we got. We sneak over into their neighborhood, middle of the night, grab a little something back, something they didn't even know they had, something they can't even recognize no more! [...] No. Can't be anti-Europe when everybody's part of Europe. But got to be pro-Africa, for the same reason" (TS 573).

Joey believes that "Whatever dream my brother and I had been raised on was dead" (TS 577). Yet the conjunction of musical discourse with the scientific discourse on Time seems to open the possibility of other existence. Combining a complex musical structure of counterpoint with Einsteinian notions of relative time, the novel frequently turns back on itself in temporal and musical loops of "unchanging change" for example, when Jonah, at the very beginning of the book, singing John Dowland's "Time stands still with gazing on her face," wants to stop "the melody's forward motion and collapse it into a single chord" (TS 521). Such moments of stillness are placed on what David conceives of as the curve of Time, where "events can move continuously into their own local future while turning back onto their past" (TS 476).

The novel's narrated time spans a period of approximately 150 years (from 1843 to the mid 1990s), yet it concentrates on a smaller temporal frame of sixty years - moving constantly forward and backward in time between the 1930s and the 1990s. Although the narration can be said to slowly progress in broken-up chronological sequence from the foundational moment of the family's history (Delia's and David's meeting at Easter 1939 till Jonah's death in 1992), it can also be seen as sliding backwards, since it begins in 1961 and ends in 1939. In doing both, it weaves a complex temporal space that, although in constant motion, also stands still, returning frequently in shorter or longer 
temporal leaps and loops to moments of suspended time: that of Jonah's triumph in a singing competition, December 1961, which marks the beginning of the book (as much as of Jonah's fated career); Delia's death in 1955 (when Ruth sings Bach's "Bist du bei mir," a song of their common childhood that she will sing again at her brother's funeral in 1992); and the moment of David's and Delia's first encounter at Marian Anderson's concert in Washington, Easter 1939, which is recounted four times from slightly different perspectives. The novel thus revolves around three temporal still-points (returning twice to 1961, three times to 1955 and four times to 1939), from which the future can be remembered and the past anticipated:

Our father discovers how time is not a string, but a series of knots. Not straight through, but turning back on ourselves, harmonizing with bits we've already sung through, accompanying those nights we haven't yet sung. (TS 522).

31 The narrative, in following this temporal spiral, contracts time by telescoping several generations in a recurrent name (like Delia or Ode). However, it bends back most often to the utopian, the foundational moment of trans-racial union: Delia's and David's meeting at Marian Anderson's concert at the Lincoln Memorial in 1939. Due to the novel's peculiar temporal structure, this moment is rendered not only as remembered past but also as remembered future, as a past that is already 'in' the future - a moment in time out of time. "She doesn't anticipate what will happen to her so much as she remembers it," the narrator says of his mother; "[...] memory must already hold all prophecies yet to come home" (TS 525). ${ }^{15}$ David's abstract speculations thus become concrete experience in the book's narrative universe: time moves at different speeds, temporality is pluralist: there is no single now, or rather: now happens on different temporal levels, ${ }^{16}$ as in that final recounting of the 'utopian' moment when David and Delia, by taking care of a little black boy in search of his brother, create an emotional bond that gives them strength enough to cross racial boundaries. In this moment, not only is past re-enacted as present, but future is already present in a past repeating what is yet to come. The boy raps the words of the song that his uncle, Joey (not yet born then), will compose for him forty years later: "The bird and the fish can make a bish. The fish and the bird can make a fird" - a syncopated, desperate and yet playful stammering to which David and Celia give definite (yet hypothetical and precarious) meaning from the conviction "that all things possible must exist." Therefore: "The bird can make a nest on the water" and: "The fish can fly" (TS 631).

This pivotal moment, it seems to me, is comparable to Dewey's “deep-seated memory of underlying harmony, the sense of which haunts life like the sense of being founded on a rock" (Dewey 17). It marks the continuous need for belonging as much as for transcultural crossing and merging on which Powers rests his narrative mediation between cultures, and which is also a meditation on hybridity. From this "still-point" the universalist dream is redefined: not beyond or above the reality of race but through the concrete particularity of its experience: "Not beyond color, into it. Not or; and. And new ands all the time" (TS 627). For Powers, it is precisely the undeniable reality of particularity which makes his art question any coercively universal notion of shared values and traditions ("the old imperial dream of coherence") and yet re-open, through his novel's communicative power, the possibility of such sharing beyond the boundaries and ruptures of difference. muss alles möglich zu machen seyn' (GV 127). It is a central motif in all of Powers's 
fiction expressing a vision that, as Bradford Morrow argues, is "essentially celebratory. Bachlike" (Morrow). In the earlier Gold Bug Variations, Powers had pursued it in the opposite direction and explored its ambivalent, if not sinister, implications (as he would again later, in Plowing the Dark). Should everything possible also become real? For Ressler, ${ }^{17}$ the genetic scientist in the Gold Bug Variations, the power of the human imagination to create reality also raises the question of its ethical responsibility:

What exactly did the phrase mean? 'Everything that is, is possible' was possible, if redundant. 'All things that might be, can be' rubbed up in my mind against unlikelihood. Yet an evolutionist might say the same. All permutations on an amino acid theme are possible; given sufficient time and the persistent tick of the mutation clock, everything might be tried, with varying success. Not every experiment will fly; but every conceivable message string is - whatever the word means - possible. The mind, emerging from blind patterning in possession of catastrophic awareness, condensed the eon-work of random field trials into instants. Did Bach's baroque ditty harbor the political horrors of Ressler's own lifetime? Everything that humans can image will be implemented. Bergen-Belsen, Nagasaki, Soweto, Armenia, Bhopal: he had lived through all manner of atrocity. These mutations too were built on the little phrase, and then some. To listen to a theme and variations, he suggested, one had to be prepared for dissonance severe enough to destroy even the original theme (GV 192-193).

This is the quasi-musical "Base" of Powers's work, its thematic center, its harmonic vision built on "catastrophic awareness." The pendulum swing between its sinister and its more hopeful ${ }^{18}$ implications which characterizes all of Powers's work goes into the 'dark' direction in The Goldbug Variations and Plowing the Dark; but, in The Time of Our Singing, it moves into the other. Whereas, in the field of science, not everything that might be should be (GV 193), in the field of culture, Bach's dictum becomes a plea for the reality of the particular since, in Powers's fictional world, the free unfolding of the imagination (life's mind) is concurrent with the evolutionary unfolding of life itself. Within this cultural field, fiction is the privileged space of "symbolic transaction" in which the possibly real is ethically tested through and against experience. Herein lies fiction's political and cultural significance - its function for the mind's survival. ${ }^{19}$ And it is here that the culturally possible can be said to realize itself, against a coercive concept of cultural unity, in the push for cultural mutation and diversity. However, the universal survives in the very process of its unceasing transformation. Powers' fiction, as much as Bach's contrapuntal music, hovers "around the fixed center of diatonic time" (GV 578). They are both "tightly bound, symmetry-laced catalog[s] of unity" in which structure may be repeated but in which "nothing was the same as anything else" (GV 586). They thus form "an imperceptibly vast chaconne, an evolutionary passacaglia built on repetition and recycling" (GV 578) whose basic unity is realized in the very plenitude of its possible variations but whose polyphonic harmonies neither deny nor hide the reality of the abyss. 


\section{BIBLIOGRAPHY}

\section{WORKS CITED}

Berger, Kevin "Richard Powers, “The Art of Fiction CLXXV." The Paris Interview 164 (Winter 2003): 1-32.

http://www.parisreview.com/tpr164/powers1.html and

http://www.parisreview.com/tpr164/powers2.html.

Dewey, John. Art as Experience. 1934; New York: Perigee Books, 1980.

Harris, Charles B. “Technoromanticism and the Limits of Representationalism : Richard Powers's Plowing the Dark." Science, Technology, and the Humanities in Recent American Fiction. Ed. Peter Freese and Charles B. Harris. Essen: Die Blaue Eule, 2004. 249-278.

Hendricks, Jefferson, "Richard Powers: On the Novel in the Digital Age." Poets and Writers (July/ August 2000).

Hurston, Zora Neale. "Characteristics of Negro Expression." The Norton Anthology of African American Literature. Ed. Henry Louis Gates, Jr. and Nellie McKay. New York: W. W. Norton, 1997. 1019-32.

Lightman, Alan. Einstein's Dreams. New York: Warner Books, 1994.

Menand, Louis. The Metaphysical Club. New York: Farrar, Strauss and Giroux, 2001.

Mendelsohn. Daniel. “A Dance to the Music of Time.” New York Times 26 Jan. 2003, Section 7.

Morrow, Bradford. "A Dialogue - Richard Powers and Bradford Morrow." Conjunctions 34 (Spring 2000):1-12.

http://www.conjunctions.com/archives/c34-rp.htm.

Neilson, Jim. "Interview with Richard Powers." The Review of Contemporary Fiction 18.3. (Fall 1998).

Powers, Richard. The Time of Our Singing (TS). New York: Farrar, Strauss and Giroux, 2003.

---. Plowing the Dark (PD). New York: Farrar, Strauss and Giroux, 2000.

---. Gain. New York: Farrar, Strauss and Giroux, 1998.

---. Galatea 2.2. New York: Farrar, Strauss and Giroux, 1995.

---. The Gold Bug Variations (GV). New York: Morrow, 1991.

---. "Being and Seeming: the Technology of Representation." Context: a Forum for Literary Arts and Culture (2000). online edition.

Styron, William. "Afterword." The Confessions of Nat Turner.

Williams, Jeffrey. “The Last Generalist - Interview with Richard Powers.” Cultural Logic 2: 2 (Spring 1999): 1-16.

http://eserver.org/clogic/2-2/williams.html.

---. “The Issue of Corporations: Richard Powers' Gain.” Cultural Logic 2 (Spring 1999): 1-7.

http://eserver.org/clogic/2-2/Williamsrev.html. 


\section{NOTES}

1. "A lot of my books have been structured around this idea of an a-synchronous messaging, that there are two or more stories going on in different moments in time that are somehow trying to signal each other, trying to open a conversation between time periods that ought to be sealed off one from the other as far as any ongoing message. But in the moment of being reconstituted in the reader's brain those messages between past, present, and future are, I hope, detonating all the time" (Powers in Hendricks). The phrase "remembering forward" is taken from the same interview.

2. "In so many ways, my books mean to counter the unquestioned ascendancy of the technological world, the tacit assumption that we have to do what our inventions tell us to do, the blind acceptance of market-driven determinism" (Powers in Williams, "The Last Generalist" 13).

3. It is particularly a newspaper account of an instance of racism that makes Helen decide that she doesn't "want to play anymore" (GV 314).

4. In his interview with Jim Neilson Powers argues: "It's becoming clear to me that Galatea was a kind of closing chapter on my first five books, which I published over the course of a decade. The autobiographical fiction in that story gave me a chance to do a personal look back over the shape of those narratives. It also allowed me one last intimate occasion to address the issue that ties all of these books together: the apology for fiction in a postfictional age" (Powers in Neilson). As to the "autobiographical fiction," without insisting on it too much, its traces seem to be quite consciously laid throughout the early novels, most visibly in Galatea, whose protagonist is a fictional Richard Powers who has a beloved professor of English, Taylor, whose name is a straight translation of the German name of the actual Richard Powers's English professor, Robert Schneider. In Operation Wandering Soul, the protagonist's name Richard Kraft is an obvious translation of Powers's name into German (although the grim world of the Los Angeles children's hospital is that of his older brother). In addition, this novel makes extensive use of Powers's own adolescent years in Thailand. In Three Farmers..., Prisoner's Dilemma and The Gold Bug Variations there are evident parallels in age between the novels' protagonists and the writer's. In the latter novel, the flighty genius Todd is born on June the 18th, 1957, which is also the birthday of his maker.

5. "Remember that the actively narrating conscious brain is not arbitrary; it is itself the evolutionary product of several billion years of bumping up against the world... We may live our lives as a tale told, but the tale we tell takes its shape from the life we are limited to" (Powers in Nielson). With reference to Plowing the Dark, Harris argues "that Powers is self-consciously manipulating the codes and conventions of representational realism, that, indeed, Plowing the Dark is not a realistic novel so much as it is a simulation of mimetic form, which Powers's imitation of an imitation critiques" (Harris 267).

6. "I'll start by writing these books that are enraptured by certain resonant connections between art and technology and consciousness. But writing those works creates an instability in my own sense of worldly accountability, and that sense of instability leads me to write novels that return to the world of political events and material conditions [...]. I guess what I'm saying is that as I get older, my real goal as a writer seems to be to make a book that links up pure aesthetic wonder and astonishment with a more mature 
accountability to intractable social questions" (Powers in Williams, "The Last Generalist" 14).

7. In his two plot-lines, two very unequal individuals are dialogically set against each other: the large corporate unit ("the individual that the limited-liability corporation literally is in the eyes of the [American] law") and the "flesh-and-blood" private individual that is exposed to this mass of corporate individuality. See his interview with Bradford Morrow and also Williams, "The Issue of Corporations: Richard Powers' Gain." 8. With some exaggeration one might argue that Powers connects the history of the soap business with the patterns of the soap opera. In the private plot-line he makes, in any case, use of the conventions of domestic fiction.

9. In the same interview, Powers also argues: "A huge portion of our lives, even as measures from within this fictional construction of the individual - which Gain goes to great pains to see as a by-product of the rising technological and corporate world - will always play out in the public sphere, in the social confrontations of polis-making" (Powers in Williams, "The Last Generalist" 12).

10. Cp. Richard Powers's short essay "Being and Seeming," where he writes: "The more advanced the media, the higher the level of mediation. The hypersymbolic nature of the digital - the fact that its descriptions have that odd ability to rise up and walk leaves it particularly vulnerable to this mistake. More than ever, we are in danger of reifying our artifacts, of mistaking them for a priori entities.... The problem with the digital promise lies not in its frivolity or its shallowness. (Remember that only upon its deathbed has the novel no longer needed to defend itself from being only a novel.) The problem with the digital promise lies in its potential depth, in the degree and the force of an emulation that might make us content to take the map for the place, the sign for the thing signified" (Powers, "Being and Seeming").

11. In one of several interviews on Plowing the Dark, Powers describes Adie and Taimur's encounter as a "metaphor for reading; that's what reading does. In the end, the book becomes an apology for the virtuality of fiction, fiction not as a replacement for the real world, but as a hybrid place where the real world is suspended and reconstituted into something more survivable" (Powers in Harris 273). In an interview he gave to The Paris Review, Powers states that he got the idea for the book when he heard Terry Waite sum up his five-year captivity in Beirut in the "shocking" statement that "Contemporary humanity has lost the ability to engage in productive solitude" (Powers in Berger 1, 1).

12. "The key insight in all my research was that everything in America, all events, all people, all situations, will be viewed differently, depending on your racial identification. That blacks and whites simply do not share the baseline common assumptions about things. But little by little, it started to feel incredibly liberating and salubrious to think that we didn't all have to be in the same place, and that this twotakes-on-everything can provide an incredibly rich possibility for depth perception. It moved me out of my baseline cultural assumptions, far enough so that I could see those assumptions. Further, the train of thought that the multiplicity might somehow be as enabling as it was threatening moved me to contemplate the nature of racism itself" (Powers in Berger 2,1).

13. Such questions were raised in connection with William Styron's The Confessions of Nat Turner (1967). By putting himself into the place of the Other (or, less kindly, by putting on the black mask of the minstrel show), Styron not only gave in to the "spell of négritude," his lifelong "secret passion for blackness" (Styron, "Afterword" 436), but 
also accepted the challenge to represent an experience that was "essentially foreign to his own world" (453). Powers ran into much less hostile criticism - although one critic called it in barbed praise "the best white novel about blacks" (as quoted in the blurb of the paperback edition).

14. Cp. Zora Neale Hurston, "Characteristics of Negro Expression" 1025.

15. This peculiar structure of time (of timeless change or changing timelessness) is emphasized again and again since it makes, in part, for the book's topic as much as for the manner of its telling: "She hears effect before cause, response before call: her own daughter singing to her, the one tune that will do for her funeral" (TS 524);

"Somewhere, our future is already real, although we can't yet know how real, stuck as we are in the specious present" (TS 95); "Time backward and time forward: Both are always. The universe does not make a difference between the two. Only we do" (TS 355). 16. David's (and Powers's) inventions of different non-linear manifestations of time (of speed and structure) run parallel to Alan Lightman's in Einstein's Dreams (1994).

Lightman (who is a writer and a physicist) imagines the different shapes the lives of people take when placed within different frames of time - reinventing Einstein's dreams while he developed his theory of relativity in the spring and summer of 1905: time contains an in finite possibilities of different times and worlds. One of these is a world where "time flows at different speeds in different locations" (Lightman 154). In another, "time is like the light between two mirrors. Time bounces back and forth, producing an infinite number of images, of melodies of thoughts. It is a world of countless copies" (Lightman 165).

17. Ressler's name suggests the struggling (or wrestling) Faustian figure of the philosopher- scientist.

18. Powers does not think in terms of utopia but in those of infinite possibility. The fundamental element of 'wonder' that pervades his work and that Morrow called "celebratory", "spiritual, even religious" (Morrow) is not in anyway connected with a concept of utopian perfectionism but includes tragedy and failure. Mutations are wonderful but they can also go wrong. There is "[n]o upward march, no drive toward perfection. Evolution's move is lateral, spreading out, diversifying until every spot on the nearest-fit curve, every accidental juggle, has been auditioned against experience" (GV 251).

19. "My apology for fiction has always taken the form of saying: When we live in real time, under the onslaught of the challenges of unmediated existence, we cannot solve all the problems that are thrown at us, the problems of the physical challenge of the world, the nature and needs of others, our own internal aggressions and animosities and ambivalences. Therefore, we remove ourselves into the space of symbolic transaction. And we do that with an eye toward solving in abstract those crises, getting a handle on them in the domain where time has been suspended. And then we reenter, more fully equipped, the world of reality" (Powers in Esquire, qtd. in Harris $274 \mathrm{f} \mathrm{Fn.)} \mathrm{In}$ his interview with Jim Nielson, he argues in similar fashion for fiction's powerless power: "The problem with the world we have made is that it can't be survived without the fictional moratorium that fiction provides, but it can't be opposed adequately from within that fictional moratorium" (Powers in Neilson). 


\section{AUTHOR}

HEINZ ICKSTADT

Heinz Ickstadt, Kennedy-Institute, FU Berlin 